\title{
Faktor yang Memengaruhi Pendapatan Margin Murabahah pada Bank Umum Syariah dan Unit Usaha Syariah
}

\author{
Factors affecting murabahah margin income in Islamic commercial banks and sharia business \\ units
}

\section{Adi Yulianto}

Program Studi D4 Keuangan Syariah, Politeknik Negeri Bandung

E-mail: adi.yulianto13@gmail.com

\section{Ade Ali Nurdin}

Jurusan Akuntansi, Politeknik Negeri Bandung

E-mail: ade.nurdin@polban.ac.id

\section{Ine Mayasari}

Jurusan Akuntansi, Politeknik Negeri Bandung

E-mail: ine.mayasari@polban.ac.id

\begin{abstract}
Murabahah contracts that become the most popular at Islamic banks are an important thing to study. Especially the determination of profit margins that do not have clear rules therefore things that can enlarge and reduce murabahah margin income are interesting to study. This study aims to determine the factors that can determine the murabahab margin income, as well as to find out the variables that predominantly influence the murabahah margin income. The objects used in this study are Sharia Commercial Banks and Sharia Business Units in Indonesia. The period used starts from 2014 untul 2018. The data used is secondary data then the data is processed using panel data regression method. The results show overhead costs, profit sharing of third party funds, volume of murabahah financing, and deposit rates have an influence on murabahah profit margins and inflation has no effect on murabahah profit margins. The volume of murababah financing is a factor that has a dominant influence on murabahah profit margins.
\end{abstract}

Keywords: murabaha, income, Islamic commercial banks, sharia business unit.

\section{Pendahuluan}

Akad murabahah yang hingga saat ini telah menjadi akad yang sangat populer dilaksanakan pada perbankan syariah perlu dijadikan perhatian khusus dikarenakan pendapatan perbankan syariah paling banyak berasal dari akad ini (Anisa \& Tripuspitorini, 2019). Sehingga dapat dikatakan tulang punggung operasional bank syariah adalah akad murabahabnya. Sejatinya tugas itu seharusnya dilimpahkan kepada akad kerjasama yang menjadi ciri khas perbankan syariah yaitu akad mudharabah dan musyarakah. Persoalan ini dilatarbelakangi loeh mudahnya pengelolaan bagi bank dalam menjalankan akad akad murabahah. Hubungan yang hanya sebatas pemberi dan pinjaman, bank syariah tidak harus berkecipung dalam dunia bisnis para calon nasabah. Selain bersifat investasi jangka pendek, murabahah juga menjadi akad yang dapat memberikan keuntungan yang lebih pasti dibandingkan dengan akad-akad yang lain seperti mudharabah dan juga musyarakah. Margin yang dapat dirubah sedemikian rupa pula yang membuat bank syariah nyaman dalam mengelola pembiayaan murabahah. Margin keuntungan murabahah yang penentuannya tidak diatur 
secara jelas oleh pemerintah ataupun badan pengawas syariah membuat persentase margin keuntungan murabahah dapat mencapai angka yang sangat tinggi. Tingginya persentase margin keuntungan memungkinkan angsuran pembiayaan murabahah menjadi lebih besar dibandingkan dengan angsuran kredit pada perbankan konvensional.

Tabel 1. Perbandingan Angsuran Kredit dan Pembiayaan

\begin{tabular}{|l|r|l|r|}
\hline Bank Konvensional & Angsuran/bulan & \multicolumn{1}{|c|}{ Bank Syariah } & Angsuran/Bulan \\
\hline BCA & Rp. 4.953.000 & BNI Syariah & Rp. 5.532.000 \\
\hline BRI & Rp. 4.951.775 & BCA Syariah & Rp. 5.584.000 \\
\hline BNI & Rp. 4.982.005 & Bank Muamalat & Rp. 5.399.505 \\
\hline Rata-Rata & Rp. 4.962.260 & Rata-Rata & Rp. 5.501.962 \\
\hline
\end{tabular}

Sumber: Dari berbagai sumber, data diolah kembali

Dewasa ini rata-rata angsuran bank syariah dapat mencapai kurang lebih 10\% lebih besar dibandingkan dengan angsuran yang ada pada perbankan konvensional. Tingginya besar angsuran akad murabahah dapat menurunkan ketertarikan masyarakat untuk melakukan pembiayaan murabahah pada perbankan syariah. Ketidakjelasan ketentuan dalam menentukan margin murabahab membuat hal-hal yang dapat mempengaruhi pendapatan margin menarik untuk dikaji Dengan latar belakang tersebut dapat ditarik rumusan masalah sebagai berikut: 1. Faktor apa saja yang dapat mempengaruhi pendapatan margin murabahah dan faktor apa yang memiliki pengaruh paling dominan dalam menciptakan pendapatan margin keuntungan murababah pada Bank Umum Syariah dan Unit Usaha Syariah?

\section{Kajian Pustaka}

Menurut Muhamad (2004) yang dapat mempengaruhi margin keuntungan murababah adalah biaya overhead, cost of loanable fund, dan profit target. Didalam bukunya beliau juga menjelaskan lebih lanjut dan menyinggung beberapa hal seperti biaya gaji, biaya penyusutan aktiva tetap, biaya penyisihan penghapusan aktiva, biaya yang berhubungan dengan administrasi dan umum serta biaya lainnya yang digolongkan menjadi biaya overhead dari suatu bank. Biaya biaya ini akan ditutupi oleh adanya pendapatan yang diterima oleh bank yang salah satunya adalah berasal dari margin murabahah. Atas dasar hal tersebut maka dapat dibuat hipotesisi bahwa biaya overhead dapat mempengaruhi pendapatan margin murabahah (H1).

Selain biaya overhead, beliau juga menjelaskan bahwa margin keuntungan tidak luput dari pengaruh atas kewajiban bank kepada nasabah dalam bentuk bagi hasil dana pihak ketiga. Sama halnya dengan biaya overhead, karena bagi hasil ini akan dianggap seperti biaya, maka bank akan berusaha menutupinya dengan adanya pendapatan yang dihasilkan dari berbagai akad dimana pendapatan yang paling besar berasal dari akad murabahah. maka dapat dibuat hipotesis berupa bagi hasil dana pihak ketiga memiliki pengaruh secara signifikan terhadap pendapatan margin murabahah (H2).

Besarnya pembiayaan murabahah yang disalurkan kepada masarakat dapat juga mempengaruhi kenaikan dan penurunan dari pendapatan yang diperoleh dari margin keuntungan murabahah. Volume pembiayaan murabahah yang didasarkan kepada jumlah penyaluran dana pada akad murabahah dapat dipengaruhi oleh perbedaan jenis dan harga dari komoditas yang diperjual belikan di dalam akadnya. Semakin mahal harga perolehan dari suatu komoditas maka akan menciptakan pembiayaan bank dalam bentuk akad murabahah yang besar pula. Semakin besar pembiayaan secara langsung akan menghasilkan margin keuntungan yang besar. Maka hipotesis 
dapat dibuat bahwa volume pembiayaan murabahah dapat mempengaruhi pendapatan margin murabahah (H3).

Suku bunga deposito diduga mempengaruhi naik turunnya margin keuntungan murabahah dikarenakan bagi hasil dana pihak ketiga akan menggunakan suku bunga deposito sebagai acuan agar dapt bersaing dengan bank konvensional. Agar dapat menciptakan bagi hasil yang kompetitif dengan bank konvensional maka perbankan syariah akan mengacu kepada suku bunga. Diharapkan dengan kompetitifnya bagi hasil dengan suku bunga akan menarik nasabah untuk menyimpan dananya pada perbankan syariah. Berdasarkan hal tersebut maka dapat dibuat hipotesis bahwa pendapatan margin murabahah dapat dipengaruhi oleh adanya suku bunga deposito (H4).

Muhamad (2004) mengatakan bahwa inflasi dapat mempengaruhi margin keuntungan murabahah sesuai dengan pernyataan Rivai dan Andria dalam Wahyudi (2017) bahwa bank akan sangat rentan dengan adanya resiko inflasi terkait dengan mobilitas dananya. Maka untuk menanggulangi adanya resiko inflasi bank kan menciptakan margin keuntungan yang disesuaikan dengan adanya tingkat inflasi. Akibannya pendapatan bank akan meningkat. Sehingga dapat dibuat hipotesis bahwa tingkat inflasi memiliki pengaruh terhadap pendapatan margin murabahah (H5).

Selain pernyataan Muhamad, Karim (2010) juga menjelaskan bahwa penetapan margin keuntungan murabahah dapat mempertimbangkan beberapa hal yaitu DCMR, ICMR dan ECRI. Pertimbangan ini biasanya didiskusikan pada rapat tim ALCO (Asset Liabilities Commitee) yaitu rapat tim yang dibuat oleh bank yang akan mendiskusikan berbagai macam hal yang berkaitan dengan strategi dan keputusan yang akan diambil oleh bank yang diantaranya adalah penetapan margin keuntungan murabahah. menurut beliau bank akan mempertimbangkan kondisi dari bank pesaing yaitu bank syariah yang lain sebagai bentuk kompetitor tidak langsung dengan melihat tingkat margin rata-rata perbankan syariah dan juga bank konvensional sebagai bentuk dari kompetitior tidak langsung dengan melihat suku bunga. Selain dua kondisi tersebut, sama halnya dengan pernyataan Muhamad, Karim juga menjelaskan adanya expected return yang kompetitif dengan bank konvensional dapat menentukan margin keuntungan murabahah pada perbankan syariah. semakin besar bagi hasil atau expected return yang diharapkan oleh para nasabah penyimpan dana maka dapat memperbesar keuntungan atau pendapatan margin murabahah.

\section{Metode Penelitian}

Objek sekaligus poplulasi aygn digunakan pada penelitian ini adalah Bank Umum Syariah dan Unit Usaha Syariah yang terdaftar pada Otoritas Jasa Keuangan dengan pengambilan sampel menggunakan metode probability sampilng dengan teknik cluster random sampling dimana kelompok bank yang teramassuk kedalam BUS dan kelompok bank yang termasuk UUS akan dipilih secara random atau acak pada setiap masing masing kelompok dengan memberikan peluang yang sama bagi setiap anggota dari kelompok tersebut. Bank-bank yang terpilih berdasarkan hal tersebut adalah BRI Syariah, Muamalat, Mega Syariah, Bukopin Syariah, CIMB Niaga, OCBC NISP, Danamon, dan Permata. Data yang digunakan dalam penelitian ini adalah data sekonder dalam bentuk data gabunga atau data panel. Data berasal dari publikasi laporan triwulan masing masing bank yang terpilih dengan kurun waktu dati 2014 hingga 2018. Software Eviews menjadi software pilihan penulis yang digunakan untuk pengolahan data. Evews dipilih karena dirasa lebih cocok untuk digunakan pada bentuk data gabungan antara time series dan cross sections atau biasa disebut data panel.

\section{Hasil dan Pembahasan}

\subsection{Pemilihan Model}

Pemilihan metode perlu dilakukan dalam pengolaha data panel. Pemilihan metode ini didasarkan oleh hasil uji Chow, uji Hausman, dan uji Lagrange Multiplier. 
Tabel 2. Uji Chow

Redundant Fixed Effects Tests

Equation: Untitled

Test cross-section fixed effects

\begin{tabular}{lrrr}
\hline \hline Effects Test & Statistic & d.f. & Prob. \\
\hline \hline Cross-section F & 81.669089 & $(7,147)$ & 0.0000 \\
Cross-section Chi-square & 253.918184 & 7 & 0.0000 \\
\hline \hline
\end{tabular}

Setelah dilakukan uji Chow didapatkan hasil berupa nilai Probabilitas Chi Square sebesar 0,000 yang artinya metode yang terpilih adalah metode Fixed Effect dibandingkan dengan metode Common Effect. Selanjutnya diujikan kembali untuk menentukan metode terbaik antara Fixed Effect dan Random Effect melalui uji Hausman.

Tabel 3. Uji Hausman

Correlated Random Effects - Hausman Test

Equation: Untitled

Test cross-section random effects

\begin{tabular}{lrrr}
\hline \hline Test Summary & $\begin{array}{r}\text { Chi-Sq. } \\
\text { Statistic }\end{array}$ & Chi-Sq. d.f. & Prob. \\
\hline \hline Cross-section random & 0.000000 & 5 & 1.0000 \\
\hline \hline
\end{tabular}

Hasil uji Hausman menunjukan bahwa nilai probabilitas 1,000 yang artinya metode yang terpilih atau terbaik untuk digunakan sebagai estimator adalah dengan menggunakan metode Random Effect. Karena yang terpilih adalah Random Effect maka selanjutnya perlu dilakukan uji Lagrange Multiplier untuk menentukan model terbaik antara Random Effect dan Common Effect.

Tabel 4. Uji Lagrange Multiplier

\section{Lagrange multiplier Tests for Random Effects}

Null hypotheses: No effects

Alternative hypotheses: Two-sided (Breusch-Pagan) and one-sided

(all others) alternatives

\begin{tabular}{lccc}
\hline \hline & \multicolumn{3}{c}{ Test Hypothesis } \\
& Cross-section & Time & Both \\
\hline \hline Breusch-Pagan & 235.5685 & 45.07439 & 280.6429 \\
& $(0.0000)$ & $(0.0000)$ & $(0.0000)$ \\
\hline \hline
\end{tabular}

Didapatkan hasil dari uji Lagrange Multiplier adalah nilai probabilitas sebesar 0,000 yang memiliki makna bahwa metode terbaik yang dapat digunakan sebagai estimator adalah metode Random Effect. Kemudian model di uji normalitasnya dengan melihat nilai Jarque-bera. 

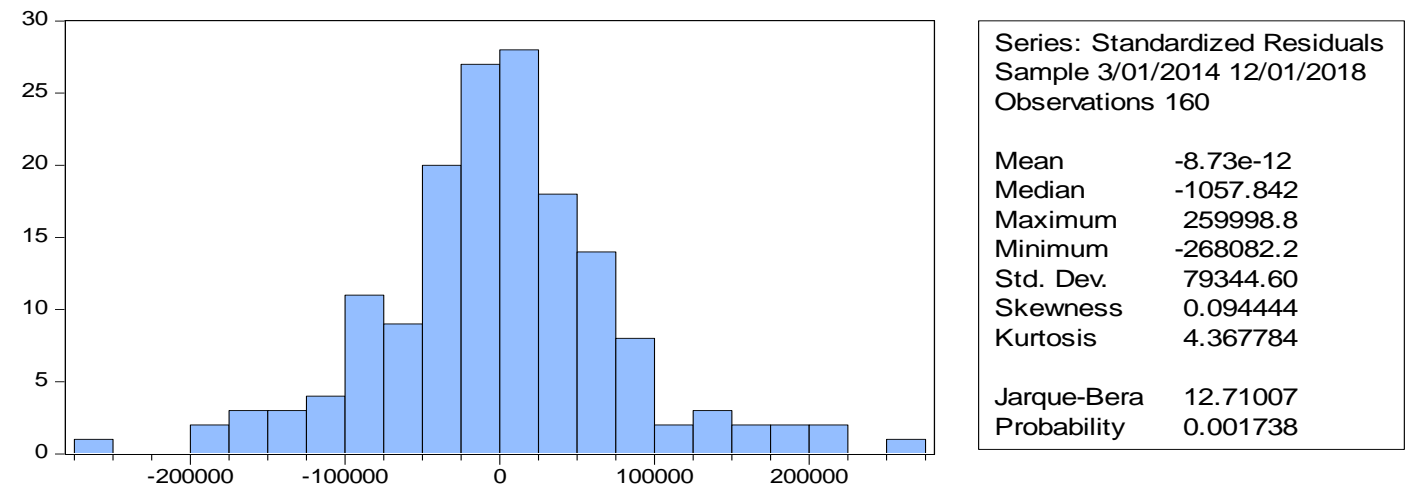

Gambar 1. Uji Normalitas pertama

Didapatkan hasil nilai Jarque-bera sebesar 0,0017 dimana nilai tersebut lebih kecil dibandingkan nilai kritis atau tingkat kepercayaan sebesar 0,05. Artinya model tidak lulus uji normalitas sehingga perlu dilakukan treatment berupa pentransformasian data menggunakan logaritma natural $(\mathrm{Ln})$. Bentuk persamaan regresi awal yaitu:

$$
\mathrm{MM}=\mathrm{c}+\mathrm{BO}+\mathrm{BDPK}+\mathrm{VP}+\mathrm{SBD}+\mathrm{I}
$$

Kemudian ditransformasikan menjadi bentuk logaritma natural atau Ln sebagai berikut:

$\operatorname{LnMM}=\mathrm{c}+\mathrm{LnBO}+\mathrm{LnBDPK}+\mathrm{LnVP}+\mathrm{SBD}+\mathrm{I}$

Berikut adalah hasil perhitungannya kembali setelah data ditransformasi.

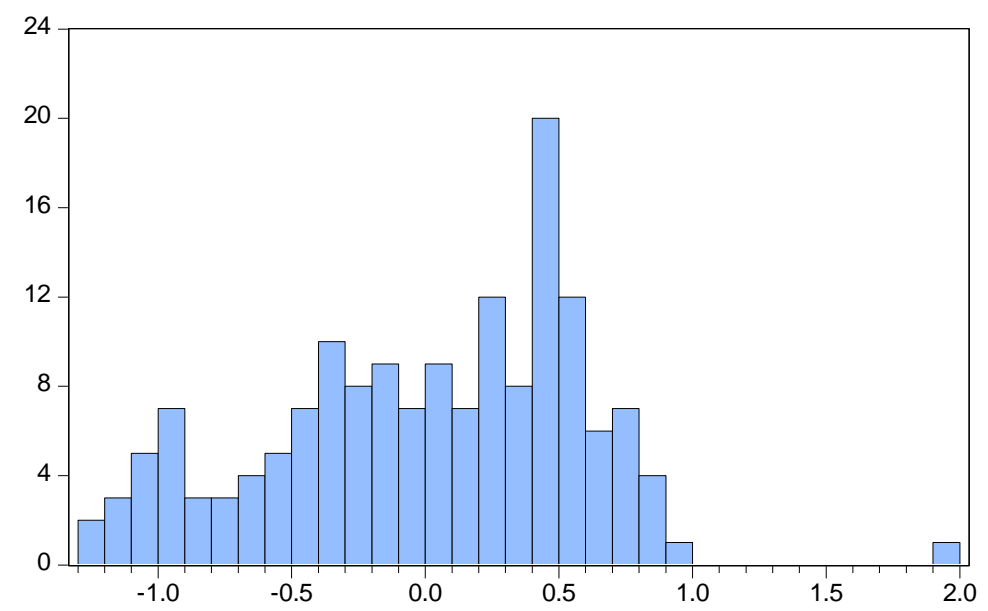

\begin{tabular}{|lc|}
\hline \multicolumn{2}{|l|}{ Series: Standardized Residuals } \\
Sample 3/01/2014 12/01/2018 \\
Observations & 160 \\
Mean & $2.09 \mathrm{e}-15$ \\
Median & 0.065488 \\
Maximum & 1.995315 \\
Minimum & -1.274120 \\
Std. Dev. & 0.577045 \\
Skewness & -0.212355 \\
Kurtosis & 2.844295 \\
& \\
Jarque-Bera & 1.364155 \\
Probability & 0.505565 \\
\hline
\end{tabular}

Gambar 2. Uji Normalitas setelah transformasi

Setelah model di uji kembali normalitasnya, didpatkan nilai Jarque-bera sebesar 0,505 yang mana nilai tersebut lebih besar dari nilai kritis yang artinya data yang digunakan telah terdistribusi normal.

\subsection{Uji Asumsi Klasik}

\section{Uji Multikolinearitas}

Jika suatu model mengalami gejala multikolinearitas maka dapat dikatakan bahwa model tetap tidak bias tetapi model tersebut dapat kehilangan keefienannya.uji multikoliearitas dapat dilakukan dengan cara mengkorelasikan masing -masing dari variabel bebas terhadap variabel bebas lainnya. 
Tabel 5. Uji Multikolinearitas

\begin{tabular}{c|c|c|c|c|c}
\multicolumn{7}{c}{ Correlation } \\
\hline & BAGI_HASIL... & \multicolumn{1}{c}{ INFLASI } & OVERHEAD & SUKU_BUN... & VOLUME \\
\hline BAGI_HASIL... & 1.000000 & -0.148567 & 0.897478 & -0.080141 & 0.742388 \\
\hline INFLASI & -0.148567 & 1.000000 & -0.101425 & 0.767708 & 0.004989 \\
\hline OVERHEAD & 0.897478 & -0.101425 & 1.000000 & -0.034336 & 0.700638 \\
\hline SUKU_BUN... & -0.080141 & 0.767708 & -0.034336 & 1.000000 & 0.004556 \\
\hline VOLUME & 0.742388 & 0.004989 & 0.700638 & 0.004556 & 1.0000000 \\
\hline & & & & & \\
\hline
\end{tabular}

Menurut Ghozali (2013) suatu data mengalami gejala multikolinearitas apabila korelasi antar variabel bebas memiliki nilai yang melebihi 0,90 . Berdasarkan gambar diatas, nilai korelasi antar variabel bebas tidak ada melebihi 0,90 . Artinya data tidak terjadi gejala multikolinearitas.

Menurut Gujarati (2009) metode penelitain yang berbentuk OLS (Ordinary Least Square) contohnya metode CEM dan FEM harus melewati uji asumsi klasik meskipun tidak semua uji harus dilakukan. Lebih lanjut beliau menjelaskan bahwa metode Generalized Least Square (GLS) dapat menghasilkan model yang bersifat BLUE (Best Linier Unbiased Estimator). Generalized Least Square (GLS) adalah bentuk perubahan metode OLS yang sudah dapat memuaskan asumsi klasik.

\section{Uji Heteroskedastisitas}

Uji heteroskedastisitas dapat dilakukan dengan metode Glejser, yaitu dengan meregresikan variabel bebas dengan nilai absolut dari residualnya.

Tabel 6. Uji Heteroskedastisitas

Dependent Variable: RESABS

Sample (adjusted): 3/01/2014 12/01/2018

Periods included: 20

Cross-sections included: 8

Total panel (balanced) observations: 160

\begin{tabular}{lrlrl}
\hline \multicolumn{1}{c}{ Variable } & Coefficient & Std. Error & t-Statistic & Prob. \\
\hline \hline C & -0.464644 & 0.370767 & -1.253197 & 0.2120 \\
BAGI_HASIL_DPK & 0.021847 & 0.063860 & 0.342102 & 0.7327 \\
INFLASI & 0.014489 & 0.022987 & 0.630309 & 0.5294 \\
OVERHEAD & 0.033212 & 0.055031 & 0.603509 & 0.5471 \\
SUKU_BUNGA_DEPOS & & & & \\
$\quad$ ITO & 0.029559 & 0.040702 & 0.726225 & 0.4688 \\
$\quad$ VOLUME & -0.000135 & 0.014114 & -0.009533 & 0.9924 \\
\hline \hline R-squared & 0.059278 & Mean dependent var & 0.477712 \\
Adjusted R-squared & 0.028735 & S.D. dependent var & 0.321461 \\
S.E. of regression & 0.316809 & Akaike info criterion & 0.575741 \\
Sum squared resid & 15.45663 & Schwarz criterion & 0.691060 \\
Log likelihood & -40.05930 & Hannan-Quinn criter. & 0.622568 \\
F-statistic & 1.940815 & Durbin-Watson stat & 0.767362 \\
Prob(F-statistic) & 0.090659 & & \\
\hline \hline
\end{tabular}

Berdasarkan hasil uji heteroskedastisitas yang menggunakan metode Glejser, didapat nilai probabilitas yang melebihi nilai kritis untuk semua variabel. Maka menurut Priyatno (2012) apabila nilai signifikansi telah melebihi nilai kritis 0,05 , maka data bersifat homogen atau dapat dikatakan 
tidak terjadi heteroskedastisitas.

Metode Generalized Least Square (GLS) sebenarnya sudah dapat menghilangkan adanya heteroskedastistas pada suatu data (Gujarati \& Porter, 2009). Karena salah satu tratment agar model terbebas dari gejala heteroskedastisitas adalah dengan menggunakan metodel GLS. Berdasarkan hal diatas, maka model dalam penelitian terbebas dari heteroskedastisitas

\section{Uji Autokorelasi}

Untuk pengujiannya dapat dilakukan dengan menggunakan metode Durbin Watson dan juga Run Test. Metode yang paling terkenal di kalangan para peneliti adalah metode Durbin Watson.

Terdapat banyak pendapat bahwa uji autokorelasi tidak perlu dilakukan pada data yang berbentuk panel dikarenakan autokorelasi lebih sering terjadi pada data time series dibandingkan dengan data cross section sedangkan data panel lebih menyerupai data cross section dibandingkan data time series.

Tabel 7. Uji Autoorelasi

\begin{tabular}{llll}
\hline \hline R-squared & 0.929914 & Mean dependent var & 4.442648 \\
Adjusted R-squared & 0.927638 & S.D. dependent var & 1.183595 \\
S.E. of regression & 0.318389 & Sum squared resid & 15.61122 \\
F-statistic & 408.6576 & Durbin-Watson stat & 1.875665 \\
Prob(F-statistic) & 0.000000 & & \\
\hline \hline
\end{tabular}

Hasil uji Autokorelasi dengan menggunkan metode Durbin Watson didapatkan nilai DW sebesar 1,875. Angka tersebut harus dibandingkan dengan nilai yang terdapat pada tabel Durbin Watson. Dengan jumlah data sebesar 160 (n) dan jumlah variabel bebas sebanyak 5 (k), maka didapatkan nilai dL sebesar 1,677 dan nilai dL sebesar 1,806. Berdasarkan hasil tersebut maka nilai DW berada diatas dU dan masih berada di bawah nilai 4-dL (dU $<$ DW $<4$-dU). Maka dapat disimpulkan bahwa tidak terjadi masalah autokorelasi.

\subsection{Hasil Analisi Regresi Data Panel}

Bedasarkan model estimasi yang terpilih yaitu random effect yang kemudian telah diujikan dengan asumsi klasik, berikut ini merupakan hasil analisis regresi data panel dengan menggunakan alat bantu software EViews ver 9:

Tabel 8. Analisis Regresi Data Panel

Dependent Variable: MARGIN_MURABAHAH

Method: Panel EGLS (Cross-section random effects)

Sample (adjusted): 3/01/2014 12/01/2018

Periods included: 20

Cross-sections included: 8

Total panel (balanced) observations: 160

Swamy and Arora estimator of component variances

\begin{tabular}{crrrr}
\hline \hline Variable & Coefficient & Std. Error & t-Statistic & Prob. \\
\hline \hline C & -9.359370 & 0.377217 & -24.81161 & 0.0000 \\
BAGI_HASIL_DPK & 0.215122 & 0.051765 & 4.155784 & 0.0001 \\
INFLASI & -0.022512 & 0.016715 & -1.346806 & 0.1800 \\
OVERHEAD & 0.551909 & 0.050459 & 10.93773 & 0.0000 \\
SUKU_BUNGA_DEPOSITO & 0.182077 & 0.029428 & 6.187130 & 0.0000 \\
VOLUME & 0.722987 & 0.018846 & 38.36217 & 0.0000
\end{tabular}




\begin{tabular}{llrr}
\hline \hline & \multicolumn{2}{l}{ Effects Specification } & \\
& & S.D. & Rho \\
\hline \hline Cross-section random & & 0.121309 & 0.2204 \\
Idiosyncratic random & & 0.228143 & 0.7796 \\
\hline \hline & \multicolumn{2}{l}{ Weighted Statistics } & \\
\hline \hline R-squared & 0.929914 & Mean dependent var & 4.442648 \\
Adjusted R-squared & 0.927638 & S.D. dependent var & 1.183595 \\
S.E. of regression & 0.318389 & Sum squared resid & 15.61122 \\
F-statistic & 408.6576 & Durbin-Watson stat & 1.875665 \\
Prob(F-statistic) & 0.000000 & & \\
\hline \hline
\end{tabular}

Berdasarkan hasil dari tabel diatas maka dapat diperoleh persamaan regresi sebagai berikut: $\mathrm{MM}=9.35937+0.55190 * \mathrm{BO}+0.21512 * \mathrm{BDPK}+0.72298 * \mathrm{VP}+0.18207 * \mathrm{SBD}-0.02251 * \mathrm{I}$

Standardized coefficient dapat digunakan sebagai alat ukur untuk menentukan faktor mana yang memiliki pengaruh paling dominan. Nilai standardized coefficient didapatkan dengan mengalikan besar koefisien variabel bebas dengan standar deviasinya setelah dibagi dengan standar deviasi dari variabel terikat. Variabel bebas yang memiliki nilai standardized coefficient paling besar diantara variabel bebas lainnya, maka variabel tersebut dapat dikatankan memiliki pengaruh paling dominan diantara variabel bebas lainnya (Gujarati, 2009). Setelah dilakukan perhitungan tersebut, volume pembiayaan murabahah memiliki nilai standardized coefficient paling besar diantara variabel lain yaitu sebesar 0,73 yang dapat dimaknai bahwa volume pembiayaan murabahab harus menjadi perhatian bagi perbankan syariah baik itu bank umum syariah maupun unit usaha syariah guna mengoptimalkan pendapatan karena volume pembiayaan adalah faktor yang memliki pengaruh paling dominan diantara variabel independen lain yang digunakan pada penelitian ini terhadap pendapatan margin murabahah.

\subsection{Koefisien Korelasi}

Dilihat dari hasil pengolahan data diatas, terdapat nilai $\mathrm{R}$ squared sebesar 0,929. Dengan mengakar kuadratkan nilai dari $\mathrm{R}$ squared tersebut maka akan didapat nilai koefisien korelasi atau yang biasa disebut juga dengan nilai $\mathrm{R}$ yang digunakan untuk mengetahui tingkat hubungan antara variabel bebas dengan variabel terikat yaitu sebesar 0,964 . Nilai $R$ memiliki angka yang mendekati 1, artinya tingkat hubungan antara variabel bebas dan variabel terikat adalah sangat kuat.

\subsection{Koefisien Determinasi yang Disesuaikan (Adjuster $\mathbf{R}^{2}$ )}

Berdasarkan hasil diatas dihasil nilai adjusted $\mathrm{R}$ squared sebesar 0,927 yang artinya 92,7\% variasi pengaruh pendapatan margin murabahah dapat dijelaskan oleh variasi pengaruh variabel bebas dalam penelitian yaitu biaya overhead, bagi hasil dana pihak ketiga, volume pembiayaan murabahah, suku bunga deposito, dan inflasi. Sisanya sebesar 6,3\% dijelakan oleh faktor lain diluar atau tidak termasuk dalam penelitian ini.

\subsection{Uji t (Parsial)}

Tabel 8 dapat menunjukan nilai koefisien yang dapat digunakan untuk menguji seberapa jauh pengaruh variabel independen didalam model mempengaruhi variabel dependen secara parsial. Nilai probabilitas dapat digunakan sebagai cara untuk menjawab beberapa hipotesis yang telah diajukan pada penelitian ini. Berdasarkan nilai probabilitas dan nilai koefisien maka didapatkan hasil sebagai berikut: 
a) Biaya overbead memiliki nilai probabilitas sebesar 0,0000. Angka tersebut memiliki nilai yang lebih kecil dibandingkan nilai kritis yaitu sebesar 0,05. Artinya biaya overhead ini memiliki pengaruh secara signifikan terhadap variabel terikat yaitu pendapatan margin murabahah. Besar angka koefisien memiliki nilai yang positif yaitu sebesar 0,55. Angka yang bernilai positif menunjukan bahwa hubungan antara biaya overhead dan pendapatan margin murabahab adalah berbanding lurus. Maknanya adalah apabila biaya overhead mengalami pertumbuhan sebesar satu satuan, maka pendapatan margin murabahah akan mengalami pertumbuhan sebesar 0,55 satuan. Disimpulkan hipotesis alternatif H1 yaitu biaya overhead memiliki pengaruh secara signifikan terhadap pendapatan margin murabahah dapat diterima.

b) Bagi hasil dana pihak ketiga memiliki nilai probabilitas sebesar 0,0001 yang lebih kecil dibandingkan nilai kritis yaitu sebesar 0,05. Artinya bagi hasil dana pihak ketiga memiliki pengaruh secara signifikan terhadap variabel terikat yaitu pendapatan margin murabahah. Besar angka koefisien memiliki nilai yang positif yaitu sebesar 0,21 memiliki makna bahwa apabila bagi hasil dana pihak ketiga mengalami pertumbuhan sebesar satu satuan, maka pendapatan margin murabahah akan mengalami pertumbuhan sebesar 0,21 satuan. Disimpulkan hipotesis alternatif $\mathrm{H} 2$ yaitu bagi hasil dana pihak ketiga memiliki pengaruh secara signifikan terhadap pendapatan margin murabahah dapat diterima.

c) Volume pembiayaan murabahah memiliki nilai probabilitas sebesar 0,0000 yang lebih kecil dibandingkan nilai kritis yaitu sebesar 0,05 . Artinya volume pembiayaan murababah memiliki pengaruh secara signifikan terhadap pendapatan margin murabahah. Besar angka koefisien memiliki nilai yang positif yaitu sebesar 0,72 memiliki makna pertumbuhan volume pembiayaan sebesar satu satuan maka akan mempengaruhi pertumbuhan prndapatan margin murabahah sebesar 0,72 satuan. Disimpulkan bahwa hipotesis alternatif H3 yaitu volume pembiayaan murabahah memiliki pengaruh secara signifikan terhadap pendapatan margin murabahah dapat diterima.

d) Suku bunga deposito memiliki nilai probabilitas sebesar 0,0000 yang lebih kecil dibandingkan nilai kritis yaitu sebesar 0,05. Artinya suku bunga deposito bank konvensional memiliki pengaruh secara signifikan terhadap pendapatan margin murabahah pada perbankan syariah. Besar koefisien sebesar $+0,18$ memiliki makna bahwa jika suku bunga deposito mengalami kenaikan sebesar satu satuan, maka akan mempengaruhi pendapatan margin murabahah akan meningkat sebesar 0,18 satuan. Disimpulkan hipotesis alternatif H4 yaitu suku bunga deposito memiliki pengaruh secara signifikan terhadap pendapatan margin murabahah dapat diterima.

e) Faktor inflasi memiliki nilai probabilitas sebesar 0,18. Berbeda dengan faktor lain, faktor ini memiliki nilai probabilitas yang lebih besar dari 0,05. Maka inflasi tidak memiliki pengaruh secara signifikan terhadap pendapatan margin murabahah. Hipotesis altenatif H5 yaitu inflasi memiliki pengaruh secara signifikan terhadap pendapatan margin murababah tidak dapat diterima.

\subsection{Uji F (Simultan)}

Hasil regresi menunjukan variabel bebas yang digunakan dalam penelitian ini secara simultan atau bersama-sama mempengaruhi variabel terikat ditunjukan dengan nilai probability F-statistik yang lebih kecil dari nilai kritis, maka dapat disimpulkan bahwa biaya overhead, bagi hasil dana pihak ketiga, volume pembiayaan murabahah, suku bunga deposito dan juga inflasi secara bersama-sama atau simultan dapat mempengaruhi pendapatan margin murabahah.

\subsection{Pembahasan}

Hasil dari kelima variabel diatas menunjukan nilai koefisien beta yang berbeda-beda. Untuk menentukan variabel mana yang memiliki pengaruh paling dominan terhadap pendapatan margin murabahah adalah dengan melihat nilai koefisien beta yang terbesar diantara variabel bebas lainnya. Berdasarkan hasil perhitungan regresi data panel diatas, didapatkan bahwa variabel volume 
pembiayaan murabahah memiliki nilai standardized coefficient yang lebih besar dibandingkan dengan variabel lainnya. Hal ini mengindikasikan bahwa volume pembiayaan murabahah memiliki pengaruh yang paling dominan diantara variabel lain didalam penelitan ini terhadap margin keuntungan murabahah.

Beberapa penelitian yang dilakukan dengan menggunakan objek berupa perbankan syariah di Indonesia menyatakan bahwa biaya overhead dapat mempengaruhi pendapatan margin murabahah seperti halnya penelitian yang dilakukan oleh Isnaliana (2015) dan juga Dewi (2010) yang menyatakan hal serupa. Tetapi terdapat juga penelitian yang menghasilkan hal yang bertentangan dengan pernyataan diatas yaitu penelitian yang dilakukan oleh Rahma (2016) yang menyatakan bahwa biaya overhead tidak mempengaruhi penetuan margin murabahah sebagai komponen pendapatan murabahah pada bank syariah di Indonesia. Penelitian ini membuktikan bahwa biaya overhead memiliki pengaruh terhadap pendapatan margin murabahah. Karim (2010) menjelaskan bahwa biaya overhead dapat dijadikan sebagai referensi dalam menentukan margin keuntungan murabahah. Didukung pula oleh pernyataan Muhamad (2004) dalam bukunya yang menyatakan bahwa biaya overhead dapat mempengaruhi naik turunnya margin keuntungan. Dalam pandangan Islam juga memperbolehkan biaya overhead ini masuk sebagai beban atau biaya karena dianggap sebagai biaya langsung yang berkaitan dengan perolehan barang komoditi (Isa dkk, 2011). Penulis berpendapat bahwa biaya overhead dapat menjadi faktor yang mempengaruhi pendapatan margin murabahah karena di dalam prakteknya, bank umum syariah maupun unit usaha syariah akan berusaha menutup biaya operasional bank yang didalamnya terdapat biaya overhead seperti biaya gaji untuk karyawan, biaya penyusutan, biaya penyisihan pengahapusan aktiva dan biaya lainnya yang berhubungan dengan administrasi dan umum dengan menggunakan keuntungan atau pendapatan yang diterima yang salah satu pendapatannya berasal dari akad murabahah. Sangat logis apabila pendapatan margin murabahah ini dipengaruhi juga oleh biaya-biaya overbead pada masing-masing bank syariah. Tetapi biaya-biaya ini perlu diefisienkan agar bank baik bank umum maupun unit usaha syariah dapat mengoptimalkan pendapatannya. Disimpulkan bahwa hipotesis H1 diterima yaitu biaya overhead memiliki pengaruh terhadap pendapatan margin murabahah.

Bank umum syariah maupun unit usaha syariah mempertimbangkan biaya bonus giro serta bagi hasil untuk tabungan dan khususnya deposito dalam menentukan pendapatan margin murabahah. Antonio (2001) juga menyatakan bahwa bagi hasil DPK diperhitungkan dalam menentukan keuntungan murabahah. Semakin besar bagi hasil yang dikeluarkan untuk membayar kewajiban, semakin besar pula keuntungan margin yang harus didapatkan. Didalam penelitian ini didapatkan hasil bahwa bagi hasil DPK mempengaruhi pendapatan margin murabahah sesuai dengan penelitian Rahma (2016) dan Zaenuri (2012) yang mengungkapkan bagi hasil dana pihak ketiga berpengaruh positif signifikan terhadap margin keuntungan murabahah. Bagi hasil merupakan suatu kewajiban bank syariah untuk memberikan sebagian pendapatannya sesuai nisbah yang telah disepakati oleh kedua belah pihak. Semakin besar bank mengeluarkan kewajibannya untuk pembagian bagi hasil bagi para nasabahnya, maka bank syariah akan berusaha untuk menutupi pengeluaran tersebut sehingga pendapatan yang diterima oleh bank pun harus semakin besar. Semakin tinggi bagi hasil DPK maka semakin tinggi pula pendapatan margin murababah. Pengeluaran ini dapat diminimalisir dengan menyalurkan dana yang berasal dari sumber dana murah seperti tabungan. Disimpulkan bahwa hipotesis H2 dapat diterima yaitu bagi hasil dana pihak ketiga berpengaruh terhadap pendapatan margin murabahah.

Berdasarkan hasil penelitian didapatkan bahwa volume pembiayaan murabahab memiliki pengaruh yang signifikan dan juga berkontribusi positif terhadap margin keuntungan murabahah. Hasil penelitain ini tidak sejalan dengan penelitian sebelumnya yang diungkapan Rahma (2016) yang menyatakan bahwa volume pembiayaan tidak memiliki pengaruh secara signifikan terhadap margin murabahah pada bank syariah di Indonesia. Tetapi hasil penelitian ini sesuai dengan pernyataan Jajuli 
(2017) yang menemukan bahwa volume pembiayaan murabahah berpengaruh positif signifikan terhadap pendapatan margin keuntungan murabahah. Didukung pula oleh penemuan Triani (2014) yang menyatakan bahwa volume pembiayaan murabahah memiliki pengaruh secara signifikan dan bernilai positif terhadap pendapatan margin murabahah. Selain berpengaruh, volume pembiayaan murabahah juga menjadi faktor yang memiliki pengaruh yang dominan terhadap pendapatan margin murabahah. Ini didasarkan kegiatan penyaluran dana dalam bentuk pembiayaan murabahab akan menghasilkan keuntungan atau pendapatan murababah seperti pernyataan yang dituliskan Purwanti (2013). Dengan menambahkan volume pembiayaan murabahah, maka penghasilan yang didapatkan dari akad murabahah akan semakin besar pula. Volume pembiayaan murabahah dapat ditingkatkan dengan cara menambah porsi dana murah seperti tabungan dibandingkan dengan sumber dana yang berasal dari nasabah deposito yang relatif ingin mencari keuntungan lebih. Dengan banyaknya sumber dana murah untuk disalurkan dalam bentuk pembiayaan terutama pembiayaan murabahah, maka persentase margin murabahah akan relatif menurun dan membuat masyarakat tertarik untuk melakukan pembiayaan murabahah. Banyaknya nasabah yang melakukan atau mendirikan akad murabahah, maka akan menciptakan volume pembiayaan murababah yang meningkat yang pada akhirnya akan meningkatkan pendapatan margin murabahah. Disimpulkan bahwa hipotesis $\mathrm{H} 3$ yang diajukan dapat diterima yaitu volume pembiayaan murabahah memiliki pengaruh terhadap pendapatan margin murabahah.

Suku bunga deposito secara tidak langsung memiliki pengaruh terhadap pendapatan margin murabahah karena suku bunga deposito dijadikan acuan untuk mempertimbangakan nilai equivalent rate deposito pada bank syariah agar dapar bersaing dengan bank konvensional. kemudian equivalent rate tersebut menjadi salah satu pertimbangan dalam menentukan persentase margin keuntungan murabahah. Sesuai dengan pernyataan Fakhrina (2015) dalam penelitiannya yang menyatakan suku bunga deposito memiliki pengaruh yang signifikan terhadap margin murabahah. Hasil penelitian ini mengemukakan bahwa suku bunga deposito memiliki pengaruh yang signifikan, maka dapat disimpulkan bahwa hipotesis $\mathrm{H} 4$ yaitu suku bunga deposito memiliki pengaruh terhadap pendapatan margin murabahah dapat diterima. Penulis berpendapat hal ini dapat terjadi karena suku bunga deposito dijadikan acuan dalam memperkirakan equivalent rate pada perbankan syariah agar tetap bisa bersaing dengan bank konvensional dalam memperebutkan sumber dana dari nasabah. Sesuai dengan pernyataan Hutapea \& Kasri (2010) dimana perilaku nasabah didorong oleh motif mencari keuntungan. Agar perbankan syariah dapat bersaing dengan bank konvensiaonl maka perbankan syariah pun perlu menarik perhatian para nasabah dengan menawarkan equivalen rate yang kompetitif dengan bank konvensioanl, sehingga dana pihak ketiga dapat ikut meningkat. Akibatnya dengan naiknya bunga deposito membuat equivalent rate pada bank syariah akan ikut meningkat sehingga untuk menutupi equivalent rate yang tinggi tersebut, bank akan berupaya salah satunya dengan meningkatkan persentase dari keuntungan akad murabahah yang berakibat pendapatan atau keuntungan yang didapatkan dari akad murabahab ini harus menjadi lebih besar.

Menurut Rivai dan Andria dalam Wahyudi (2017) menyatakan bahwa perbankan itu sangat rentan dengan adanya resiko inflasi yang berkaitan dengan mobilitas dananya. Artinya inflasi ini bisa saja mempengaruhi harga suatu komoditas yang dijalankan pada akad-akad murabahah. Berdasarkan hasil uji yang telah dijelaskan sebelumnya menunjukan bahwa inflasi dan pendapatan margin murabahab tidak memiliki pengaruh secara signifikan sehingga hipotesis H5 yaitu inflasi memiliki pengaruh terhadap pendapatan margin murababah tidak dapat diterima. Tetapi hal ini bertentangan dengan penelitian yang dilakukan oleh Satya (2013) yang menemukan bahwa inflasi memiliki pengaruh yang dominan yang dapat mempengaruhi margin keuntungan murabahab pada bank Kaltim Syariah. Tetapi hasil penelitian ini sejalan dengan penelitian dari Zaenuri (2012) yang mengungkapkan bahwa tidak ditemukannya pengaruh antara inflasi dan margin murabahah. Artinya faktor inflasi ini tidak dijadikan bahan pertimbangan didalam rapat tim ALCO (Assets Liability Committe) dalam menciptakan margin keuntungan pada akad murabahah. Penulis berpendapat bahwa 
tim ALCO lebih memfokuskan diri kepada keadaan atau kondisi dan juga kebijakan yang diambil oleh bank pesaing terutama bank konvensional terkait suku bunganya. Bank syariah akan mempertimbangkan ICMR (Indirect Competitor's Market Rate) dan ECRI (Expected Competitive Return for Investor) sesuai dengan pernyataan Karim (2010). ICMR memiliki maksud bahwa bank syariah akan melihat dan mempertimbangkan tingkat suku bunga beberapa bank konvensional yang dapat dikatakan juga tingkat suku bunga rata-rata perbankan konvensional sebagai kompetitor tidak langsung. ECRI adalah ekspetasi bagi hasil yang akan diberikan bank syariah untuk para investornya. Agar investor tertarik unruk menyimpan dananya, bank syariah harus dapat memberikan bagi hasil yang setara atau lebih dari bunga yang ada pada bank konvensional. Bank syariah akan mempertimbangkan hal-hal ini agar dapat bersaing dan memiliki kelebihan-kelebihan yang tetap kompetitif dengan bank konvensional agar dapat mempertahankan nasabah dan diharapakan dapat menarik nasabah baru. Penulis berpendapat bahwa bank syariah tidak perlu memperhitungakan adanya tingkat inflasi dikarenakan di dalam suku bunga konvensional yang dijadikan acuan oleh bank syariah, bank konvensional sudah mempertimbangkan adanya inflasi sehingga suku bunga itu sendiri sudah dapat mencerminkan adanya resiko inflasi yang terjadi. Hasil penelitian ini juga menjadi bukti bahwa bank syariah dapat bertahan dengan adanya perubahan tingkat inflasi yang besar seperti kejadian krisis moneter pada tahun 1998 yang menyebabkan tergoncangnya perekonomian saat itu karena perbankan syariah tidak mempertimbangkan tingkat inflasi pada kegiatan operasionalnya.

\subsection{Implikasi Manajerial}

Hasil penelitian ini dapat dijadikan sebagai salah satu bahan pertimbangan dan juga sebagai sarana informasi mengenai apa saja faktor yang dapat mempengaruhi pendapatan margin murabahah khususnya pada bank umum syariah dan juga unit usaha syariah. Berdasarkan hasil penelitian ini, volume pembiayaan murabahah, biaya overhead, bagi hasil dana pihak ketiga dan suku bunga deposito memiliki pengaruh yang signifikan terhadap besaran pendapatan margin murabahah, sedangkan inflasi tidak memiliki pengaruh secara signifikan terhadap pendapatan margin murabahah. Disimpulkan bahwa biaya overhead, bagi hasil dana pihak ketiga dan suku bunga deposito pada bank konvesional dapat dijadikan bahan pertimbangan dalam menentukan tingkat margin murabahah yang dapat memperbesar pendapatan. Bank syariah dapat lebih memperhatikan dan melihat faktorfaktor tersebut untuk digunakan sebagai bahan pertimbangan dalam rangka merubah besaran pendapatan bank.

Berdasarkan hasil penelitian ini pula ditemukan bahwa volume pembiayaan murabahah memiliki pengaruh yang paling dominan terhadap pendapatan margin murababah dibandingkan dengan variabel yang lain. Berfokus kepada faktor yang memiliki pengaruh yang dominan dalam penelitian ini, diharapkan bank umum syariah maupun unit usaha syariah dapat lebih mempertimbangkan dan juga memperhatikan volume pembiayaan murabahabnya. Untuk mendapatkan volume pembiayaan yang besar, pihak perbankan perlu menciptakan persentase margin murabahah yang rendah di mata masyarakat, pihak bank perlu mendapatkan sumber dana selain dari nasabah deposito karena nasabah deposito mudharabah cenderung menginginkan keuntungan yang besar. Sumber dana yang murah seperti tabungan yang akan digunakan sebagai penyaluran pembiayaan akan menciptakan persentase margin murabahah yang relatif rendah dimata nasabah dan masyarakat. Dampaknya adalah dengan tertariknya masyarakat dengan pembiayaan murabahah dengan persentase margin yang relatif rendah maka akan meningkatkan volume pembiayaan murabahah dan secara otomatis dapat meningkatkan pendapatan margin murabahah bagi bank syariah itu sendiri.

Volume pembiayaan murabahah menjadi hal yang penting guna mendapatkan pendapatan yang tinggi. Salah satu cara meningkatkan volume pembiayaan murabahah tersebut adalah dengan menurunkan tingkat persentase margin keuntungannya. Selain dengan cara meningkatkan sumber 
dana murah, perbankan juga dapat melakukan efisiensi biaya yang salah satunya adalah biaya overhead. Perbankan perlu melakukan evaluasi biaya agar biaya-biaya yang dikeluarkan bank dapat terminimalisir dan tertekan. Hasilnya persentase margin murabahah dapat turun dan nasabah ataupun masyarakat dapat lebih tertarik dengan adanya pembiayaan murabahab dengan tawaran persentase margin keuntungan yang rendah. Pendapatan margin murababah bank pun akan meningkat seiring dengan volume pembiayaan murabahah yang ikut meningkat.

\section{Penutup}

Biaya overhead, bagi hasil dana pihak ketiga, volume pembiayaan murabahah dan suku bunga deposito memiliki pengaruh secara signifikan dalam mempengaruhi pendapatan margin murabahah pada Bank Umum Syariah dan Unit Usaha Syariah pada periode 2014-2018, sedangkan inflasi tidak memiliki pengaruh yang signifikan terhadap pendapatan margin murabahah pada Bank Umum Syariah dan Unit Usaha Syariah. Artinya biaya overhead, volume pembiayaan murabahah, bagi hasil dana pihak, dan suku bunga deposito menjadi beberapa faktor yang menentukan margin keuntungan murabahah sedangakan inflasi tidak digunakan dalam penentuan margin keuntungan murabahah pada Bank Umum Syariah dan Unit Usaha Syariah.

Faktor yang memiliki pengaruh dominan terhadap margin keuntungan murabahah pada Bank Umum Syariah dan Unit Usaha Syariah adalah volume pembiayaan murabahah yang memiliki nilai standardized coeffiient beta lebih besar dibandingkan dengan nilai standardized coeffiient faktor-faktor yang lain. Perbankan khususnya perbankan syariah perlu lebih memperhatikan faktor ini untuk dijadikan bahan pertimbangan dalam menentukan margin keuntungan murabababnya.

Dikarenakan terdapatnya banyak keterbatasan dalam penelitian ini, diharapkan akan lebih baik jika peneliti berikutnya dapat mengeksplorasi faktor-faktor lain yang dapat mempengaruhi margin keuntungan murabahah baik itu faktor eksternal maupun internal dan juga menambah jumlah observasi atau sampel serta rentang waktu penelitian.

\section{Daftar Pustaka}

Anisa, L. S., \& Tripuspitorini, F. A. (2019). Analisis Pengaruh Dana Pihak Ketiga, Non Performing Finance Murabahah, dan Inflasi terhadap Pembiayaan Murabahah pada Bank Umum Syariah di Indonesia. Jurnal Maps (Manajemen Perbankan Syariah), 3(1), 52-64.

Antonio, M. S. (2001). Bank Syariah: Dari Teori ke Praktek. Jakarta: Gema Insani Press

Al-Qur'an

Dewi, Sri. (2010). Penerapan Margin Pembiayaan Murabahah Pada BMT As-Salam Pacet - Cianjur. Majalah Imiah UNIKOM, Vol.9, No.2.

Fakhrina, Agus. (2015). Pengaruh Suku Bunga Kredit dan Deposito Bank Konvensional Terhadap Margin Pembiayaan Murabahah Bank Syariah di Indonesia. Jurnal Penelitian Vol. 12, No. 1

Ghozali, Imam. (2013). Aplikasi Analisi Multivariate dengan Program SPSS. Edisi Ketujuh. Semarang: UNDIP

Gujarati, Damodar N dan Dawn C. Porter (2009). Basic Econometric. New York: McGraw-Hill

Hutapea, E., \& Kasri R. (2010). Bank Margin Determination: A Comparison Between Islamic and Conventional Bank in Indonesia. International Journal of Islamic and Middle Eastern Finance and Management Vol. 3 Issue: 1

Isa, M. B., Ibrahim, M. Y., \& Hashim, H. B. (2011). Shariah On Direct and Indirect Cost in Murabahah. International Journal of Basic \& Applied Sciences IJBAS-IJENS Vol. 11 No. 2

Isa, M. B., Rahman, A. A, Hashim, H. B., \& Embong A. M. (2012). Shariah Views On the 
Components of Profits Rate in Al Murabahah Asset Financing in Malaysian Islamic Bank. International Journal of Economics and Management Engineering Vol. 6 No.7

Isnaliana. (2015). Penetapan Margin Keuntungan Murabahah: Analisis Komparatif Bank Muamalat Indonesia dan Bank Aceh Syariah. Share Vol. 4 No. 2

Jajuli, Muharis. (2017). Pengarub Volume Pembiayaan Murababah, Biaya Operasional,Inflasi dan BI Rate Terbadap pendapatan Margin Murabahab Bank-Bank Syariah. Universitas Pendidikan Indonesia

Karim, A. A. (2010). Bank Islam Analisis Fiqih dan Keuangan. Jakarta: PT Raja Grafindo Persada.

Muhamad. (2004). Teknik Perbitungan Bagi Hasil dan Pricing di Bank Syariah. Yogyakarta: UII Press

Purwanti, Arni. (2013). Analisis Kas Ratio dan Pembiayaan Murababab Pengarubnya Terbadap Pendapatan Margin Murabahah Pada Bank Muamalat Indonesia. Universitas Komputer Indonesia

Rahma, Yusro. (2016). Faktor-faktor yang Mempengaruhi Margin Murabahah Bank Syariah di Indonesia. Jurnal Ilmu Akuntansi Vol. 9 No. 1

Satya, Kenda. (2013). Faktor-Faktor yang Mempengaruhi Penetapan Margin Murabahah Pembiayaan Konsumtif di Bank Kaltim Syariah. Ekonomika Bisnis Vol. 4 No. 2

Triani, Jenni. (2014). Faktor-Faktor Yang Mempengaruhi Pendapatan Margin Murabahah Pada Bank Umum Syariah Di Indonesia Periode 2011-2013. Riau: Universitas Negeri Sultan Syarif Kasim

Wahyudi, Rilo. (2017). Pengarub ROA, DPK, Inflasi dan Bi rate terhadap Margin Pembiayaan Murabahah Perbankan Syariah Di Indonesia. Jakarta: Universitas Islam Negeri Syarif Hidayatullah.

Zaenuri, F. (2012). Analisis Pengarub Variable Biaya Operasional, Volume Pembiayaan Murabahah, Bagi Hasil DPK, Inflasi dan BI Rate Terbadap Margin Murabahab (Studi Kasus Pada PT Bank BRI Syariab). Depok: Universitas Indonesia 